\title{
Effect of drying methods on properties of green curry powder
}

\author{
Natthacha Chaloeichitratham ${ }^{1, *}$, Pornkanya Mawilai ${ }^{1}, \quad$ Thadchapong Pongsuttiyakorn ${ }^{1}$ and Pimpen \\ Pornchalermpong ${ }^{1}$
}

${ }^{1}$ Food Engineering Department, Faculty of Engineering, King Mongkut's Institute of Technology Ladkrabang, Bangkok, Thailand

\begin{abstract}
In this study, the effects of two drying methods: hot-air and freeze drying for Thai green curry paste in a terms of drying time and qualities have been investigated. The hot-air drying was carried out in tray dryer at temperature of 50,60 and $70{ }^{\circ} \mathrm{C}$. The freeze drying was carried out in freeze dryer at freezing temperature of $-20^{\circ} \mathrm{C}$, primary drying temperature of $-10^{\circ} \mathrm{C}$ and secondary drying temperature of $50^{\circ} \mathrm{C}$. Moisture content, water activity, colour, bulk density, and total phenolic content (TPC) were determined in samples. Freeze dried sample had significantly $(\mathrm{p}<0.05)$ lower moisture content, water activity, bulk density, total colour difference and browning index than hot air dried samples. For antioxidant activity, the results showed hot-air drying at $70^{\circ} \mathrm{C}$ effected highest TPC similar to freeze drying.
\end{abstract}

\section{Introduction}

Nowadays, most of people is paying an attention to healthy food. Especially, the food which have vegetables and herbs as main ingredient. Vegetables and herbs contain with many benefits such as antioxidant and phenolic compounds [1]. One of dishes used many herbs to be the main ingredient is Thai food named Thai green curry. Besides containing many benefits, Thai green curry paste is famous curry and accepted by people from the other country.

Thai green curry paste is kind of spicy paste included green chili, garlic, shallot, galangal, lemongrass and kaffir lime zest. These paste ingredients are the main power for antioxidant, anti-inflammatory and antimutation [2-3]. Short shelf-life of green curry paste is caused containing high moisture content over 70 percentage. There are several products was created for extending the paste shelflife such as green curry paste in retort pouch or saterilized canned. However, the quality of ingredients is reduced by these process and cost of transportation is been higher from the higher weight [4]. With all of these reasons, drying a green curry paste was created for reducing the transportation cost and extended shelf-life of the paste.

To antimicrobial by reducing moisture content and water activity from a green curry paste is the process most selected by entrepreneurs. In present, there are many ways to drying a product but the easy and low-cost way, which is selected by entrepreneurs, is hot air drying; nevertheless, nutrition, flavor and colour of food were reduced by hot air-drying process [5-6]. The research of Huttakovit et al. in 2007 [7] found that high temperature was caused curry paste turns more browning as same as the research of Inchuen et al. [8] and Kausilya et al. [9] said the high temperature was caused the lower quality product, especially, total phenolic content and antioxidant activity were been lower by increasing temperature. In some case, it was found that total phenolic content of some herbs increased when it passed high temperature [1]. Meanwhile, total phenolic content and antioxidant activity were reduced by drying at the lower temperature but taking longer time because some type of foods are composed with sensitive substances. Then, drying at low temperature like freeze drying was selected to be the best process to maintain the quality of food and also maintain food property as a fresh food. [10-11].

In addition, drying process and condition which effect with product qualities, physical and chemical properties were studied by many researchers. For instance, Chee fah chili [12], oregano [13], rosemary, basil, thyme, marjoram and sage [5], olive [14], aerial and leaf of coriander [15], kimchi [16], onion [18], and Thai red curry paste [8]. Following the study of An et al. [17] has been reported that antioxidant activity total phenolic content and other important substances were obtained by freeze drying which is higher than hot air drying. On the other hand, time and energy were more spent with freeze drying process and it also caused higher cost than hot air drying. Moreover, it was found that high rehydration is affected by low moisture content of freeze drying process which is not proper with some products [19-20].

In conclusion, drying method and drying temperature are directly affected with food quality. However, the comparison between hot air and freeze drying have not been performed to dried Thai green curry paste. The aim of this study was to investigate drying which affects with

* Corresponding author: ch.natthacha@gmail.com 
the qualities of green curry powder. Moisture content, water activity, colour, bulk density and total phenolic content were investigated in the study.

\section{Materials and Methods}

\subsection{Materials and chemicals}

Fresh herbs i.e. green chilli, garlic, shallot, lemon grass, galanga, kaffir lime zest and some spices (coriander seed, cumin and pepper) were purchased from local market in Khlong Luang district, Pathum Thani Province, Thailand. Folin Ciocalteu's reagent and gallic acid were sourced from Sigma-Aldrich (USA). All other chemicals and reagents were of analytical grade.

\subsection{Sample preparation}

Fresh green curry paste was prepared by blending sliced herbs, spices and seasoning together in milling machine (Ngowhuatyoo, Thailand). The $500 \mathrm{~g}$ of paste sample was packed in polyethylene bag, then frozen at $35^{\circ} \mathrm{C}$ for $90 \mathrm{~min}$ and stored at $-18^{\circ} \mathrm{C}$ until used. The initial moisture content of the green curry paste was determined as $75.9 \%$ wet basis (w.b.).

\subsection{Drying experiment}

Frozen green curry paste samples were thawed at $4^{\circ} \mathrm{C}$ in refrigerator and spread on trays of each dryer, with 5 $\mathrm{mm}$ thickness. All samples were dried until final moisture content was below $10 \%$ w.b. [9]. Dried samples were ground into powder by using electric blender (HR2118, Philips, Nederland). The powdered was keep in aluminum foil bag for further studies.

\subsubsection{Hot-air drying $(A D)$}

Fresh green curry paste samples were dried using tray dryer (Convection Dryer, KluayNamThai - KarnChang, Thailand) at constant air velocity of $1 \mathrm{~m} / \mathrm{s}$ and three different temperatures: 50,60 and $70^{\circ} \mathrm{C}$.

\subsubsection{Freeze drying (FD)}

Green curry paste samples were dehydrated in freeze dryer (Kryo 'D' Freezer, ITC, Thailand). The samples were frozen at $-50^{\circ} \mathrm{C}$ until the core temperature of samples were $-20^{\circ} \mathrm{C}$ and then were dried in primary drying at $20^{\circ} \mathrm{C}$ and $40 \mathrm{~Pa}$ vacuum pressure. After that, samples were dried in secondary drying at $50^{\circ} \mathrm{C}$ until core temperature of samples were $50^{\circ} \mathrm{C}$, the process was completed.

\subsection{Moisture content}

Moisture content was determined using hot air oven method [21]. Powder sample was dried in the oven at $100^{\circ} \mathrm{C}$ until a constant weight was achieved. Then, the following relation was used:

$$
\text { Moisture content }=\frac{\left(W_{1}-W_{2}\right)}{W_{I}} \times 100
$$

Where $W_{l}$ is weight of powder before drying $(\mathrm{g})$ and $W_{2}$ is weight of powder after drying $(\mathrm{g})$. Moisture content was expressed as percentage (wet basis). The analysis was triplicated.

\subsection{Water activity}

Air dried and freeze dried paste samples were taken around 1-2 g to determine water activity using electronic water activity meter (Decagon Model, AquaLab, USA). Three replications of water activity were performed for each sample.

\subsection{Bulk Density}

Bulk density of samples were determined according to Seerangurayar et al. [20] with some modifications. Sample receiving cup was set up distance between bottom of loading funnel and top of sample receiving cup as 15 $\mathrm{cm}$, using $60 \mathrm{~cm}^{3}$ cylindrical cup. The powder was loaded to flow through the funnel into the cup until it overflows and carefully scraped excess powder from the top of the cup by smoothly moving spatula. The cup occupied by powder was then weighed. Bulk density was expressed using the equation:

$$
\rho=\frac{m}{V}
$$

Where $\rho\left(\mathrm{g} / \mathrm{cm}^{3}\right)$ is bulk density, $m(\mathrm{~g})$ is the mass of powder samples and $V\left(\mathrm{~cm}^{3}\right)$ is the volume of receiving cup. The bulk density measurements were performed in triplicate.

\subsection{Colour and browning index}

The fresh and dry-rehydrated green curry paste samples were measured using spectrophotometer (ColorFlex, Hunter Lab, UK) in terms of CIE $L^{*}, a^{*}$ and $b^{*}$ values. $L^{*}$ represents the range from lightness to darkness $(0-100)$ of the object. $a^{*}$ indicates redness $(+)$ or greenness $(-) . b^{*}$ represents yellowness $(+)$ or blueness $(-)$. For each sample, three replications of the colour test were performed. total colour difference $(\Delta E)$ was also determined using the equation:

$$
\Delta E=\left[\left(\Delta L^{*}\right)^{2}+\left(\Delta a^{*}\right)^{2}+\left(\Delta b^{*}\right)^{2}\right]^{1 / 2}
$$

where $\Delta L^{*}=L^{*-} L_{f}^{*}, \Delta a^{*}=a^{*-} a_{f}^{*}, \Delta b^{*}=b^{*-} b_{f}^{*}$, and $L^{*}, a^{*}$ and $b^{*}$ are the colour values of sample and $L_{f}^{*}, a_{f}^{*}$ and $b_{f}^{*}$ are the colour values of fresh sample [22]

Browning index (BI) was determined using method of Park et al. [16] with slight modification. Fresh and powder samples about $1 \mathrm{~g}$ were extract with $50 \mathrm{~mL}$ of distilled water for 24 hours. The extract was filtered through Whatman No.1 filter paper (UK). The filtrate was diluted with an equal volume of $95 \%$ ethanol and then centrifuged at $4,000 \mathrm{rpm}, 4^{\circ} \mathrm{C}$ for $15 \mathrm{~min}$ by centrifuge (MIKRO 220R, Hettich, Germany). The supernatant was measured based on its absorbance at $420 \mathrm{~nm}$ using spectrophotometer (GENESYS 10S, Thermo Scientific, UK). Measurements were performed in triplicate. The BI values were expressed as absorbance per $\mathrm{g}$ dry matter. 


\subsection{Total phenolic content}

The sample extract was obtained from determination of Incheun et al. [8] with some modification. Powder (1 g) was extracted with $25 \mathrm{~mL}$ of $90 \%$ ethanol and incubated at $150 \mathrm{rpm}, 30^{\circ} \mathrm{C}$ for $24 \mathrm{~h}$. The extract was centrifuged at $6,000 \mathrm{rpm}, 4^{\circ} \mathrm{C}$ for $20 \mathrm{~min}$.

Total phenolic content (TPC) in the green red curry product extracts was determined using the FolinCiocalteu method described by Chan et al. [23] with some modifications. The diluted extract $(2.25 \mathrm{~mL})$ was mixed with $0.25 \mathrm{~mL}$ of Folin-Ciocalteau's reagent by vortex. After $5 \mathrm{~min}, 1.00 \mathrm{~mL}$ of $10 \% \mathrm{w} / \mathrm{v} \mathrm{Na}_{2} \mathrm{CO}_{3}$ was added to the mixture. The absorbance was measured at $730 \mathrm{~nm}$ using a spectrophotometer after $10 \mathrm{~min}$ reaction. Distilled water was added instead of sample taken as blank. The amount of TPC was expressed as gallic acid equivalent per $g$ dry matter.

\section{Results and Discussion}

\subsection{Effect of drying methods on drying time and properties of Thai green curry paste powder.}

Fresh Thai green curry paste with $5 \mathrm{~mm}$ thickness samples were dried with four drying methods: hot-air drying at 50,60 , and $70^{\circ} \mathrm{C}$ and freeze drying. The drying time are presented in Table 1. Freeze dry had the longest drying time with drying time of 36 hours and $40 \mathrm{~min}$. Hotair dried at $50^{\circ} \mathrm{C}$ samples went through the second longer drying time of $480 \mathrm{~min}$, while dried at $70^{\circ} \mathrm{C}$ had shortest drying time.

The drying temperature had significant difference in water activity $(\mathrm{p}<0.05)$ as shown in Table 1 . Freeze dried sample had lowest water activity of 0.129 , like the freeze drying can extremely reduce moisture content and water activity. For hot-air dried powder at $70^{\circ} \mathrm{C}$ resulted in lower water activity than dried at $50^{\circ} \mathrm{C}$ and $60^{\circ} \mathrm{C}$ due to increasing of temperature.
Bulk density is important in packaging, storage and transportation for powdered food [20]. Table 1 show the increasing of temperature caused reduction in bulk density of hot-air dried powder. The highest bulk density $\left(0.57 \mathrm{~g} / \mathrm{cm}^{3}\right)$ was at $50^{\circ} \mathrm{C}$ air drying and it was reduced by $8 \%$ at $70^{\circ} \mathrm{C}$. Whereas, freeze dried sample had lowest bulk density as $0.30 \mathrm{~g} / \mathrm{cm}^{3}$ because lyophilization during freeze drying affected high porosity in sample [24].

\subsection{Effect of drying methods on colour properties of Thai green curry paste.}

From consumer acceptance viewpoint, colour properties are very important of dried product. A main colour of Thai green curry paste is green attribute to chlorophyll from the fresh green chilli [25].

The colour values in a term of CIE $L^{*}, a^{*}$ and $b^{*}$ system of products and total colour difference $(\Delta E)$ are presented in Table 2. There were significant differences of $\Delta \mathrm{E}$ at the $95 \%$ confidence level between 4 products. Freeze dried sample had the lowest $\Delta E$ (4.13) and $\Delta E$ of 50,60 and $70^{\circ} \mathrm{C}$ hot-air dried samples were increased with temperature increasing. Due to $a^{*}$ values of dryrehydrated green curry paste from hot-air drying increased when compared with fresh sample, whereas the value of freeze dried sample was more similar than them. That can indicate products from hot-air drying were less green. The discoloration of samples during drying was related to pigment destruction, enzymatic browning and non-enzymatic browning. Hence, results showed hot-air dried samples were more influenced by browning reaction than freeze dried sample, like BI value as shown in Table 2. There was no significant difference between $B I$ value of fresh and freeze dried sample. But BI value of fresh product was significantly less than the 50,60 and $70^{\circ} \mathrm{C}$ hot-air dried samples, which indicated that brown pigments formation occurred during processes. Similar to results were obtained from Park et al. [16] which drying of kimchi.

Table 1 Drying time, moisture content and water activity of Thai green curry paste at different drying methods.

\begin{tabular}{|c|c|c|c|c|}
\hline Drying method & Drying time (min) & MC (\%w.b.) & Water activity & Bulk density (g/cm $\mathbf{~}$ ) \\
\hline AD50 & 480 & $8.71 \pm 0.15$ & $0.311 \pm 0.004^{\mathrm{d}}$ & $0.5701 \pm 0.0052^{\mathrm{d}}$ \\
\hline AD60 & 340 & $8.54 \pm 0.20$ & $0.247 \pm 0.003^{\mathrm{c}}$ & $0.5476 \pm 0.0022^{\mathrm{c}}$ \\
\hline AD70 & 250 & $8.48 \pm 0.15$ & $0.226 \pm 0.005^{\mathrm{b}}$ & $0.5262 \pm 0.0052^{\mathrm{b}}$ \\
\hline FD & 2,200 & $3.84 \pm 0.05$ & $0.129 \pm 0.008^{\mathrm{a}}$ & $0.3047 \pm 0.0010^{\mathrm{a}}$ \\
\hline
\end{tabular}

Means ( \pm standard deviation) with different superscripts in each column significantly different $(\mathrm{p}<0.05)$

Table 2 Colour values, total colour difference and browning index of green curry powder at different drying methods.

\begin{tabular}{|c|c|c|c|c|c|}
\hline Sample & $\boldsymbol{L}^{*}$ & $\boldsymbol{a}^{*}$ & $\boldsymbol{b}^{*}$ & $\Delta \boldsymbol{E}$ & BI (abs/g dry matter) \\
\hline Fresh & $37.96 \pm 0.43^{\mathrm{a}}$ & $-2.89 \pm 0.27^{\mathrm{a}}$ & $30.14 \pm 0.56^{\mathrm{a}}$ & - & $1.224 \pm 0.021^{\mathrm{a}}$ \\
\hline AD50 & $38.73 \pm 0.04^{\mathrm{b}}$ & $3.13 \pm 0.16^{\mathrm{c}}$ & $31.11 \pm 0.53^{\mathrm{ab}}$ & $6.16 \pm 0.10^{\mathrm{b}}$ & $1.368 \pm 0.007^{\mathrm{b}}$ \\
\hline AD60 & $38.28 \pm 0.33^{\mathrm{ab}}$ & $3.99 \pm 0.03^{\mathrm{d}}$ & $30.57 \pm 0.54^{\mathrm{a}}$ & $6.92 \pm 0.08^{\mathrm{c}}$ & $1.346 \pm 0.003^{\mathrm{b}}$ \\
\hline AD70 & $38.04 \pm 0.10^{\mathrm{a}}$ & $3.92 \pm 0.30^{\mathrm{d}}$ & $32.09 \pm 1.38^{\mathrm{b}}$ & $7.17 \pm 0.18^{\mathrm{d}}$ & $1.409 \pm 0.010^{\mathrm{c}}$ \\
\hline FD & $41.34 \pm 0.13^{\mathrm{d}}$ & $-1.04 \pm 0.11^{\mathrm{b}}$ & $31.57 \pm 0.35^{\mathrm{ab}}$ & $4.13 \pm 0.05^{\mathrm{a}}$ & $1.226 \pm 0.018^{\mathrm{a}}$ \\
\hline
\end{tabular}

Means ( \pm standard deviation) with different superscripts in each column significantly different $(\mathrm{p}<0.05)$ 


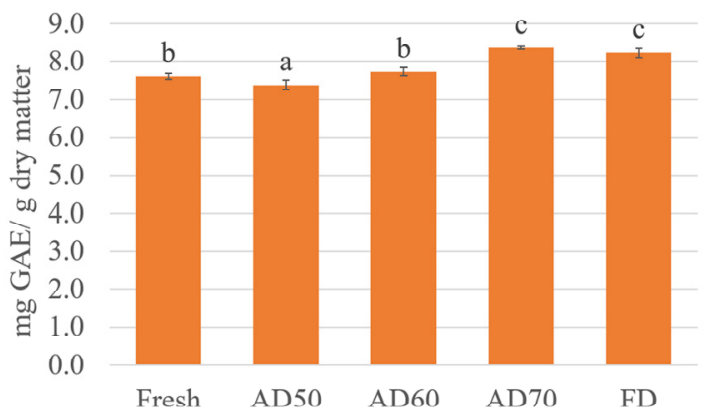

Fig. 1. Total phenolic content of fresh and dried green curry paste products.

\subsection{Effect of drying methods on total phenolic content of Thai green curry paste powder.}

In addition, TPC is one of the most important properties that indicates health benefit of the paste. Fig. 1 show TPC of four dried samples. It has been found that there was a significant difference at the $95 \%$ confidence level between hot-air and freeze dried sample at $50^{\circ} \mathrm{C}$. Freeze dried powder was much higher than hot-air dried powder. Similar to results were obtained from Asami et al. [26] which reported that freeze dried marionberry, strawberry and corn had higher TPC hot-air dried samples. During hot-air dry process, the product is dried at atmospheric pressure whereas there is very little oxygen in the freeze drying chamber, which is the cause of oxidation reaction [27]. For effect of temperature of hotair drying, it was found that TPC was increased when temperature was increased. Due to the higher temperature would promote decomposition of complex phenolic compounds affected higher TPC [17].

\section{Conclusion}

Based on the results of present investigation, properties of dried Thai green curry paste products were significantly affected by drying techniques. Freeze drying took longest drying time. However, physical properties of Thai green curry paste powder from freeze drying were lower than hot-air dried products. The lowest percentage of moisture content was freeze dried powder, whereas it had no significant difference among hot-air dried powder. Similar to water activity, freeze dried powder had lowest water activity. But water activity of hot-air dried samples were decreased when temperature was increased. And bulk density of freeze dried sample was lowest. For colour properties, it was found that freeze drying gave lowest $\Delta \mathrm{E}$ and BI value. The results of TPC showed that hot-air drying at $70^{\circ} \mathrm{C}$ effected highest TPC similar to freeze drying.

\section{Acknowledgements}

The authors also thank to I.T.C (1993) CO., LTD Thailand for freeze dry machine (Kryo 'D' Freezer) supporting.

\section{References}

1. K. Ruanma, L. Shank, and G. Chairote, Maejo Int. J. Sci. Technol, 4, 193 - 200 (2010)
2. B. Lee, J. Jung, and H. Kim, Food Chem Toxicol, 50, 3912 - 3919 (2012)

3. N. Zobia, C. Zhihui, W. Cuinan, W. Yanbin, and D. Haiyan, Postharvest Biol Technol, 131, 39-45 (2017)

4. K. Laohasongkram, S. Chaiwanichsiri, and O. Chanprasartsuk, Proceedings of the 1st International Conference on Science and Applied Science, 1, 306311 (2006)

5. M.B. Hossain, C. Barry-Ryan, A.B. Martin-Diana, and N.P. Brunton, Food Chem, 123, 85 - 91. (2010)

6. C. Borompichaichartkul, KMUTT R\&D J., 35, $269-$ 283. (2012)

7. W. Huttakovit, W. Khuikhoen, K. Mongkolwan, N. Suteebut, J. Boonyasawat, and N. Sakulyeunyongsuk, RMUTP Research J., 1, 9 - 20 (2007)

8. S. Inchuen, W. Narkrugsa, and P. Pornchaloempong, Kasetsart J. (Nat. Sci.), 44, 142 - 151 (2010)

9. S.R. Kausilya, S.T. Farah, M.Z.A. Mazidah, and R.I.S. Mohammad, J Saudi Society of Agri. Sci. (2017) (In Press)

10. L. Ma, H. Chen, W. Zhu, and Z. Wang, Food Res Int. 50, 633 - 640 (2013)

11. T.L. Jeng, C.C. Lai, T.C. Liao, S.Y. Lin, and J.M. Sung, J Food Drug Anal, 23, 701 - 708 (2015)

12. N. Toontom, M. Meenune, W. Posri, and S. Lertsiri, Int. Food Res J, 9, 1023 - 1031 (2012)

13. K. Jałoszyñski, A. Figiel, and A. Wojdyło, Acta Agrophysica, 11, 81 - 90 (2008)

14. M.H. Ahmad-Qasem, E. Barrajón-Catalán, V. Micol, A. Mulet, and J.V. García-Pérez, Food Res Int, 50, 189 - 196 (2013)

15. A.G. Pirbalouti, S. Salehia, and L. Craker, J Appl Res Med Aromat Plants, 4, 35 - 40 (2017)

16. H.J. Park, Y. Lee, and J.B. Eun, Biocatal Agric Biotechnol, 5, 193 - 198 (2016)

17. K. An, D. Zhao, Z. Wang, J. Wua, Y. Xu, and G. Xiao, Food Chem, 197, 1292-1300 (2016)

18. F. Ren, C.A. Perussello, Z. Zhang, J.P. Kerry, and B.K. Tiwari, LWT - Food Sci. Technol., 87, 102 111 (2018)

19. J.J. Ma, X.Y. Mao, Q. Wang, S. Yang, D. Zhang, S.W. Chen, and Y.H. Li, LWT - Food Sci. Technol. 56, 296 - 302 (2014)

20. T. Seerangurayar, A. Manickavasagan, M.A. Abdulrahim, and A.A. Yaseen, J Food Eng. 215, 33 43. (2017)

21. AOAC, Official Methods of Analysis of AOAC INTERNATIONAL 17th ed. (The Association of Official Analytical Chemists, Maryland, 2000)

22. S. Phoungchandang, and S. Saentaweesuk, Food Bioprod Process, 89, 429-437 (2011)

23. E.W.C. Chan, Y.Y. Lim, S.K. Wong, K.K. Lim, S.P. Tan, F.S. Lianto, and M.Y. Yong, Food Chem, 113, 166-172 (2009)

24. Y.H. Roos, Phase Transitions in Foods (Academic Press, San Diego, 1995)

25. S. Hemathulin, and S. Techawongstien, Khon Kaen Agr. J., 42, 760 - 765 (2014)

26. D.K. Asami, Y.J. Hong, D.M. Barrett, and A.E. Mitchell, J. Agric. Food Chem, 51, 1237-1241 (2003)

27. G.J. Leusink, D.D. Kitts, P. Yagnmaee, and T. Durance, J. Food Sci., 75, 311-316 (2010)

* Corresponding author: ch.natthacha@gmail.com 